\title{
Effect of Democratized Teaching Method on Secondary School Students Academic Achievement in Agricultural Science
}

Nzeribe, T.A.K

Nzetangee009@yahoo.com

Ofodile, S.N

Unigwe, L.O

unigwe6@yahoo.com

School of Agriculture / Home Economics Federal College of Education (Technical), Umunze-Anambra State, Nigeria

Doi:10.5901/ajis.2013.v2n5p187

Abstract

The study was carried out on the relative effectiveness of discovery (democratic) and lecture teaching methods on enhancing student's achievement in agricultural science. Four co-educational schools in Orumba South of Anambra State were purposively selected through random sampling. A total of 125 SSI agricultural science students were drawn from these schools. The assignment of intact class to both the discovery method group and lecture method group was done randomly. Quasiexperimental was the design adopted. The agricultural topics were taught by their teachers for a total of four periods of 35 minutes each per group. The experimental were taught with discovery method while the control group were taught using lecture method. A 40 - item agricultural science achievement test developed by the researchers was used to assess the subjects achievement Data Collected were analyzed using percentage, mean and ANOVA. The finding revealed that the experimental group (discovery method) achieved higher than the control group (Lecture). Based on the finding, the researchers recommended that democratic teaching method should be employed in teaching agricultural science.

\section{Introduction}

Effective teaching is the primarily concerned with setting up a learning activity for each student which if successful brings about the type of learning the teacher intends. Okoli and Ofodile (2006) stated that worthwhile learning partnerships develop on a variety of contexts when teachers and learners seek knowledge together, also learners construct meaning when they challenge their knowledge and understanding and respond to the challenges of others, participate in a variety of formal and informal, social and cultural interaction.

Academic achievement is the yard stick for measuring learning. It follows that poor academic achievement indicates no, little or insufficient learning. Learning is a relatively permanent change in behavior arising from experiences Offorma (2003) defined learning as the process through which behaviour is initiated, modified and change. Onwuegbune (1996) defined learning as the permanent acquisition and habitual utilization of the newly acquired knowledge and experience, learning is a process through which students acquire attitude, knowledge and skills. Learning is believed to be facilitated and more effective through the active participation of the learner. The learner cannot be active if he is not involved. It is what the learner does that he learns and not what the teacher does. When learners are involved they are themselves as part of the plan. Based on that teaching methods and strategies employed in teaching should be those that allow the learners interact with their physical environment. The method and strategies employed should enable learners 
touch, see, hear, feel, think and act in their physical environment for meaningful and effective learning to take place.

Educational research on the quality of teaching and learning processes is becoming increasingly important due to its place in instructional delivery (Schrefiele, Krapp, 1995). The search for teaching capable of ensuring students understanding is largely motivated by the fact that traditional teaching methods have failed to enable students retain what they have learnt hence the recent interest in democratized method of instruction. The popular method of instruction in secondary schools in Nigeria is the lecture method which is verbal presentation of the subject matter content, students are mere listeners and not active participants. Making learning an active process for the learner means democratized learning process. From the educational point of view, to democratized agricultural science teaching/learning in the classroom, methods and strategies employed by the teachers should be such that allow every learner equal opportunity to interact both physically and mentally with the curriculum content learning experiences, learning materials and every environmental factors involved for the attainment of pre-determined goals and objectives. such teaching methods and strategies include discovery method, co-operative learning etc.

Discovery method is an inquiry based constructive learning theory that takes place in problem solving situations where the learner draws on or her own past experiences and existing knowledge to discover facts and relationship and new truths to be learned (Onwuegbune, 1996). Discovery method instructional strategy encourages learner to discover relationship and methods of solution themselves, make their generalizations and draw conclusions from them (Ajewole,1995). Learners identify variable, collect data, and interpret data, then generate hypothesis in order to better describe and understand relationship between concepts. In discovery learning, participants learn to recognize problem, characterize what a solution would look like, search for relevant information, develop a solution strategy and execute the chosen strategy. It is a democratize teaching method, its efficacy in enhancing students achievement in agricultural science in comparison with that of conventional lecture method which is undemocratic is the focus of the study.

\section{Statement Of The Problem}

Academic achievement of Nigerian students in school subject including agricultural science at secondary school level has remained poor over the years (Obika, 2003). Part of the reasons advanced in explaining the possible causes of these poor achievement is poor mastery of the concepts, showing that the teaching methods employed is teacher centered and undemocratic. The learners do not interact with the curriculum content, learning experiences and teaching materials. Onyeneto and Onyibor (2000) stated that poor academic achievement suggests poor methodology of instruction and called for an indepth investigation of instructional strategies with a view of relating instructional strategies to students achievement. It is in respect of this clamor for change that many innovative strategies were developed to bring about improvement in teaching and learning of secondary school subjects. The main thrust of this study is to find out the effect of democraticzed teaching methods on academic achievements of secondary school students in agricultural science.

\section{Research Question}

The study was guided by the research question: what are the percentage scores of students taught agricultural science using discovery teaching methods and that of those taught using lecture method.

\section{Hypothesis}

The following hypothesis guided the study and was tested at 0.05 level of significance 
$\mathrm{Ho}_{\mathbf{l}}$ : There is no significant difference between the academic achievement of students taught agricultural science using the discovery method and those taught using lecture method based on their mean percentage scores in agricultural science achievement test.

\section{Method}

The Design - A quasi- experimental research design was employed. It is a quasi - experimental research design because according to Peter and Peter (1996) this design is suitable for studies where absolute control of all the variable involved cannot be achieved.

\section{Population of The Study}

The population of the study comprises of all the senior secondary school class one (SSI) agricultural science students in the state government owned schools in Orumba South education zone. The total number of students in these school that offer agricultural science is 294 (source: Education Unit, Orumba South Local Government Headquarters Umunze).

\section{Sample and Sampling Techniques}

Four co-educational schools were purposively selected through random sampling method. Consequently a total of 125 SSI agricultural science students drawn from four schools were used as the research subjects. This sample consists of 82 girls and 43 boys. The assignment of intact classes to both the discovery method group and lecture method group was done randomly using a simple ballot system. The discovery learning method group had 69 students while lecture method group had 56 students.

\section{Instrument}

An instrument known as Agricultural Science Achievement Test (AAT) was used for data collection. The agricultural achievement test was developed by the researchers. It is a 40 item multiple choice and was validated by experts from the fields of Agricultural Education and Measurement and Evaluation. The reliability of the AAT was established through trial-testing of the instrument on 30 SSI Agricultural students drawn from three schools in Orumba South not used for the study. The researchers employed the KuderRichardson formular (K - R20) in determining the reliability Coefficient of the AAT and the reliability was 0.76 .

\section{Research Procedure}

The regular teachers in the selected schools area were employed in the research process and they were given adequate orientation on the use of the instructional strategies, purpose and precautions relevant to the study. They were also given lesson plan based on the teaching strategies studied which was prepared by the researchers. 40 item agricultural science pretest was administered on the subjects before the commencement of treatment. The experimental and control groups were taught by theirs teachers, discovery method for the experimental group and lecture method for the control group. A total of four teaching periods of 35 minutes each was held for each of the two groups. After the pre-tests, the agricultural science teachers then commenced the treatments of both groups based on lesson plan given to them. After 4 weeks, the post AAT items were administered. The post AAT contained the same test item as the pre-A AT, this is used to determine the achievement of the subjects after treatment. 


\section{Methods of Data Analysis}

The researchers used the students raw scores to compute the groups mean. The hypothesis was tested using ANOVA.

\section{Results}

Table I: Mean percentage scores of students in experimental and control groups

\begin{tabular}{|l|l|c|}
\hline Group & Number & Mean $\overline{(\mathrm{x})}$ \\
\hline $\begin{array}{l}\text { Experimental group } \\
\text { (Discovery method) }\end{array}$ & 69 & 56.1 \\
\hline $\begin{array}{l}\text { Control group } \\
\text { Lecture method }\end{array}$ & 56 & 46.5 \\
\hline
\end{tabular}

Data in table I shows that students taught with discovery method (i.e. experimental group) had percentage mean score of 56.1, while those taught with lecture method (i.e. the control group) had percentage mean score of 46.5. The experimental group therefore performed better than the control group.

Table 2: Summary of analysis of variance on the achievement post test scores

\begin{tabular}{|l|l|l|l|l|}
\hline $\begin{array}{l}\text { Sources of } \\
\text { variations }\end{array}$ & Sum & Df & $\begin{array}{l}\text { Mean } \\
\text { Square }\end{array}$ & F \\
\hline Between & 2582.0 & 1 & 2582.0 & 14.348 .000 \\
\hline Within & 22134.0 & 123 & 179.95 & \\
\hline Total & 24716.0 & 124 & & \\
\hline
\end{tabular}

In table 2 the performance of students in the experimental group differ significantly from those in the control group because $\mathrm{F}(1,123)=14.348 \mathrm{P}(0.05)$. this shows that the students taught with discovery teaching methods perform significantly better than those taught with lecture method.

\section{Discussion of Results}

The results revealed that discovery method enhanced learning in agricultural science because the instructional method has a significant main effect on students academic achievement. The findings appears to make an emphatic premise which gives support to what was stated by Maduabum (1995) that teachers method can greatly affect students achievement and skills acquisition. The observed significant difference in the mean agricultural achievement scores for the two instructional groups in this study would be attributed to students improved participatory learning leading to an understanding of the concepts in agriculture. The relative superiority of the discovery method over the lecture method in enhancing students achievement could be attributed to the fact that as instructional strategy discovery method ensures active participation of students in the teaching-learning process. 


\section{Recommendations}

Based on the findings, the researchers made the following recommendations

1. In view of the relative effectiveness of discovery teaching method, seminars and workshops should be organized by relevant bodies to educate teachers on its use in teaching and learning of agricultural science.

2. The use of discovery teaching method should be given emphasis in the curriculum of pre-service teachers of agricultural science.

\section{Conclusion}

From the results obtained in the study, the researcher's advocates for the use of discovery method in classroom since it enhance students mastery of concept and also during the interaction of students in the discovery method, more of their senses are involved than in lecture method.

\section{References}

Afewole, G.A (1995) Adopting an Innovation Strategies in improving the teaching and learning of Biology in Olarewaju A.O. (ed) innovations in science Technology and mathematics .proceedings of Science Teachers Association of Nigeria conference (STAN).

Maduabum, M.A. (1995). The Relative effectiveness of the expository and Guided discovery method in Secondary school student Biology, ESUT Journal of education I (1), 122 - 131.

Obika, I.K (2003) Causes of poor academic achievement of students in Agricultural Science. Unpublished NCE project F.C.E.(T) Asaba.

Offorma, G.C. (2003) Curriculum theory and planning. Onitsha: Uni- World Education publishers.

Okoli, T.O and Ofodile S.N. (2006) Agricultural Methodology Umunze: Annyco press.

Onwuegbune, D.U. (1996) Special methods in Agriculture Unpublished lecture note. Nwafor Orizu College of Education, Nsugbe.

Onyibor, M.I.S (2000) Concept mapping system of instruction. An alternative Education Delivery System in Economics in Mougbo, S.O. (ed) National Policy on Education for Sustainable Development: issues for $21^{\text {st }}$ century faculty of Education, ESUT.

Schiefele, U.K. and Krapp, A (1995) course specific interest and extrinsic motivation as predictors of specific leaning strategies and course grades. Paper presented at the $6^{\text {th }}$ EARCT conference at Nijimegan. 
